\title{
Pulmonary rehabilitation and tuberculosis: a new approach for an old disease
}

\author{
Beatrice Mahler ${ }^{1,2}$, Alina Croitoru ${ }^{1,2, *}$ \\ ${ }^{1}$ Carol Davila University of Medicine and Pharmacy, Bucharest, Romania \\ Abstract \\ ${ }^{2}$ Marius Nasta Institute of Pneumophtysiology, Bucharest, Romania \\ English: \\ Tuberculosis (TB) is still a leading cause of morbidity and mortality worldwide. The impact on patient's life is significant, leading to \\ physical, mental and social deconditioning, not only in active TB but also in post TB sequela. Although with specific antituberculous \\ treatment sputum negativity can be achieved, TB extrapulmonary symptoms such as cachexia, muscle weakness and depression \\ may persist for a long time. \\ The pulmonary rehabilitation (PR) may be a useful tool in this patient's therapy in active and also in sequela phase. The benefits \\ of PR are: reducing symptomatology, improving the degree of functional independence and quality of life, and increasing the \\ ability to perform daily activities. This article discusses the components of a PR programme in active TB and TB sequela, and \\ the results obtained by studies so far.
}

Keywords

pulmonary rehabilitation $\bullet$ tuberculosis $\bullet$ exercise

\section{Reabilitarea pulmonară și tuberculoza: o nouă abordare a unei maladii vechi}

Rezumat

\section{Romanian:}

Tuberculoza (TB) este încă o cauză principală de morbiditate și mortalitate în lume. Impactul asupra vieții pacientului este semnificativ şi are drept rezultat decondiționarea fizică, mentală și socială, în formele active de TB, dar și în sechelele post TB. Deși cu un tratament antituberculos specific poate fi obținută negativarea sputei, simptomele extrapulmonare ale tuberculozei, ca de exemplu caşexia, slăbiciunea musculară și depresia pot persista mult timp.

Reabilitarea pulmonară (RP) poate fi un instrument util în terapia acestui pacient atăt în faza activă a bolii, dar și în perioada de sechele post TB. Beneficiile RP sunt: reducerea simptomatologiei, îmbunătățirea gradului de independentă functională si a calității vieții, creșterea capacității de a efectua activități zilnice. Acest articol discută componentele unui program de reabilitare pulmonară în TB activă și in sechelele post TB, precum și rezultatele obținute de studii până acum.

Cuvinte-cheie

reabilitare respiratorie $•$ tuberculoză • exerciţiu

\section{Introduction}

Pulmonary tuberculosis (TB) is an infectious contagious disease produced by bacteria belonging to Mycobacterium tuberculosis group (1). It is a major public health problem, being one of the top 10 causes of death worldwide. Now, the TB incidence is falling with $2 \%$ per year, but the goal of End TB strategy is to reach a $4-5 \%$ annual decline. An estimated

*Corresponding author: Alina Croitoru

E-mail: haulicaalina@yahoo.com

ว Open Access. (C) 2019 Mahler and Croitoru, published by Sciendo

(c) BY-NC-ND This work is licensed under the Creative Commons Attribution-NonCommercial-NoDerivs 4.0 License. 
54 million lives were saved through TB diagnosis and treatment between 2000 and 2017 (17 years) (2).

Even if specific anti-TB treatment leads to clinical healing and the absence of Koch bacillus in sputum culture; in some patients, anatomical lung destructions can appear, with extensive fibrosis areas. These areas usually respect the territory of former bacillary active lesions, so the lesions can be located on the lung apex or generalized to entire lung.

Thoracic post-TB impairment may be present in the bronchial airway, lung parenchyma or pleura. Pulmonary parenchyma affected by TB lesions is replaced by connective tissue, which alters lung architecture. The consequence is the appearance of scars, resting cavities, typically delimited by long-standing fibrous parenchyma strips and fibrosis, or complete lung destruction. In the bronchial tree TB processes may lead to severe alterations of bronchial structure, characterized by bronchial stenosis, bronchiectasis, bronchial fistula and bronchial lithiasis. Bronchiectasis occurs in about $20 \%$ of patients with healed pulmonary TB. Broncholithiasis is asymptomatic, but can be clinically evident when it is complicated with broncho-pulmonary fistula. TB pleurisy, despite correct therapy, may also cure with different degrees of fibrosis, leading to pachypleuritis.

TB may also influence other parts of the patient's life such as nutritional status, exercise tolerance, muscle strength, psychological status and quality of life (QOL) (3). In a group of 28 Cameroonian patients with TB, effort tolerance assessed by 6 Minutes Walk Test (6MWT) was decreased compared to control healthy subjects in the first phase of active disease, but after 2 months of specific TB drug therapy the physical capacity improved (4).

The impact of TB on QOL can be assessed with different questionnaires: St. George Respiratory Questionnaire (SGRQ), World Health Organization QOL questionnaire (5), short-form 12v2 questionnaire (SF-12v2) (6) and clinical COPD questionnaire (CCQ) (7).

\section{Pulmonary rehabilitation in tuberculosis}

Treatment of pulmonary TB usually involves a multidisciplinary approach. After the diagnosis and establishment of the therapeutic regimen, the subsequent evolution and the increase of the chances of healing and social reintegration can be done with the help of pulmonary rehabilitation (PR) and in selected cases with thoracic surgery.

$\mathrm{PR}$ is a multidisciplinary programme, addressed to patients with respiratory impairment who have impaired clinical and functional status with consequences on daily life activities and QOL $(8,9)$. This therapy is individualized and involves physical training, psychological counselling, nutritional support, along with compliance with TB drug treatment. In selected patients,
PR programmes improve symptoms, exercise capacity and social integration (8-10).

\section{Pulmonary rehabilitation in the active phase of tuberculosis}

In the active phase of TB, due to the intense chronic inflammatory syndrome that induces the release of many cytokines, tumour necrosis factor alpha (TNFa) and interleukins, patients claim weight loss, asthenia and exercise dyspnoea. Thus, inclusion of patients with TB in PR programmes is indicated due to high degree of physical and mental deconditioning. The medical recovery of these patients is complex, aiming to reach the maximum level of independence and community reintegration after hospital discharge.

\section{Exercise}

Typically, prolonged bed rest and avoidance of the exercise are recommended for patients in the active phase of TB. Although avoidance of intense exercise may be justified in some special cases (e.g. severe haemoptysis), in cases of normal TB, it may not represent an indication. It was reported, in one of the first studies in this area followed for 7 years, that 454 patients with TB placed on a programme of exercise combined with drug TB therapy. The programme consisted of exercise for arms, shoulder, elbow, knee (light and heavy exercise alternatively), bicycle exercise and occupational therapy. The results showed that early start of a complex PR programme may allow a social and work reintegration of patients with TB after hospital discharge (11).

In the active TB phase, the exercise proposed may be light in first few days, starting with passive exercise (elongations of the limbs while standing in bed), followed by activeassisted and active exercise. In physical therapy, the patient's condition will be taken into account by trying to establish a patient-friendly programme. Exercises at a slow pace will be preferred first, followed by the increase in the degree of precision and postural control. Over time, the application of motion resistance, which involves an increase in muscle strength that occurs by increasing the number of repetitions, or applying weight, will be taken into account. The exercise must target both upper and lower limbs. When the patient's status is stable, walk test may be used, in the hospital room or corridor, followed by stationary cycling and resistance training. The intensity should be progressively increased, depending on patient's individual tolerance.

Additional techniques, such as relaxation, posture and breathing education, to exercise training may be useful. For example, diaphragmatic breathing aims to improve the effectiveness of their contraction by conscious relaxation of the abdominal wall with decreased respiratory effort; it involves inspiration followed by expiration from abdominal 
muscle action. Later, progressively increasing weights will be applied to the abdomen, performing the same movement.

A recently published study in Ukraine investigates the effects of a multidisciplinary rehabilitation programme on 68 newly diagnosed patients with TB. They were divided into two groups, 34 patients each: (1) a control group containing TB drug therapy + usual rehabilitation and (2) a study group receiving TB drug therapy + multidisciplinary comprehensive PR programme. The PR programme included gymnastic, therapeutical massage, physiotherapy, hydrotherapy and therapeutic education. In patients receiving a comprehensive $\mathrm{PR}$ programme, there was an increase in lung function, QOL questionnaire (WHOQOL-100 quality of life of the World Health Organization) and cardiovascular and respiratory system status (assessed by hypoxic samples) (5).

\section{Nutrition}

Malnutrition appears to increase the risk of TB; people with a low body mass index are more at risk of developing TB than those with a high body mass index. Moreover, the underweight patients with TB are at risk for delayed healing, TB relapses or increased mortality. The weight loss and muscular mass are associated with fatigue and decreased exercise capacity, and there is a risk for the patient to not recover the body weight at the end of drug therapy, despite receiving correct TB treatment (12).

The initial medical assessment of respiratory patients must include nutritional status, the determination of body weight and body composition. The underweight COPD patients with a BMl lower than $21 \mathrm{~kg} / \mathrm{m}^{2}$ have a decreased percentage of fat mass than normal-weight patients (13). In the case of TB patients, although fat-free mass (FFM) seems to be in closer relation with physical status and $\mathrm{QOL}$ than body weight and fat mass (FM), there is an increase of FM during the healing period (14).

Proper nutrition is an important element in all stages of TB infection. Among underweight patients at the time of diagnosis, those who gain $5 \%$ by weight in the first 2 months of treatment have low rate of recurrence than those who gain less than $5 \%$ (15). Nutritional supplementation may have a positive role in these patients recovery. Adding highcalorie supplements for patients with TB in first phase of the treatment has to be shown to have benefits on lean mass, body weight and physical function after 6 weeks (16). Trials reported that vitamins and minerals (thiamine, vitamins $B 6, C$, $E, A$ and zinc) were effective in improving immune response and the good response to chemotherapy (number of patients with negative sputum) (17).

\section{Therapeutic education}

TB is a contagious disease that induces fear, social isolation and need a long period of drug administration, sometimes with adverse effects. Therefore, therapeutic education is very important, which serves the purpose in explaining the patients and their family about the condition of the disease, the risks of contagiousness, the stages of treatment and prognosis. Proper medical education can influence the patient's adherence to treatment as well as improve the patient's mood and perception of the disease. The educational programme is better to be started in the hospital where it is easier to organize both individual and group trainings. For patients with TB who are active smokers, smoking cessation interventions should be initiated; these had been shown to improve the results of TB drug therapy (18).

\section{Psychological support}

Emotional support must be provided to patients with TB and their families during illness. Receiving TB diagnosis is often regarded by the patient as a real stigma which isolates him from family and society. A community-based study from the World Health Survey on 242.952 subjects showed an incidence of depressive syndrome of $23.7 \%$ in patients with TB, compared with $6.8 \%$ in the control group (19). The psychologist can support patients to help reduce misconception and to socially integrate former patients (Table 1).

\section{Pulmonary rehabilitation in post tuberculosis sequelae} Unlike COPD, in post TB sequelae, there is a lack of studies regarding the effects of PR. Most therapies in this chronic phase of disease include bronchodilators, inhaled corticotherapy, oxygen therapy and in selected cases, surgery (20). However, the studies performed so far with regard to PR in TB sequelae showed positive results in exercise tolerance, symptoms and QOL (7, 21-23).

In post TB sequelae, the rehabilitation target two directions: the symptoms related to bronchiectasis and the muscular weakness leading to functional impairment and dyspnoea.

\section{Physiotherapy for bronchiectasis}

When the TB heals with sequelae bronchiectasis, symptoms such as bronchorrhea, respiratory infections and haemoptysis may influence the patient's QOL. In these cases, the airway

Table 1. Modalities of psychosocial support

\begin{tabular}{ll}
\hline Types of mental dysfunction & Types of intervention \\
\hline Intra-psychic conflict, low & - group therapy, psychoanalysis \\
self-esteem, lack of control & - emotions management \\
& - hypnoses \\
Relationship with others/environment: & - education, information \\
decreases the desire for information, & - occupational therapy \\
communication and lack of skills & - communication programmes \\
Psychiatric acute states: panic, anxi- & - stress management \\
ety and depression & - relaxation techniques \\
& - hypnoses \\
\hline
\end{tabular}


clearance technique is an important therapeutical tool with positive effects: reduced sputum quantity, better ventilation and relief of symptoms $(8,24)$.

Postural drainage is considered to be the most effective means of ensuring evacuation of secretions from the bronchial tree. Its principle is based on the use of positions that create a gradient of height between the pulmonary segment loaded with secretions and the large bronchial paths and trachea; position favouring gravity action on fluid leakage. The most effective position is tattooed at first sessions with the physical therapist. Sometimes, a few degrees of torso rotation can visibly collapse the evacuation of the secretions (15). It must be done before a meal, once or several times a day, but not more than 20-30 min, during which time several positions will be used, 5-10 min each. At the end of each position period, the drained region will be tap for $1 \mathrm{~min}$.

Another techniques used to diminish the sputum load are as follows: autogenic drainage, forced expiration, vibrations with special devices and manual procedures such as clapping and percussions. Now we discuss the active cycle of breathing techniques. ACBT is a simple breathing technique used to clear lung secretions, to improve cough efficiency and ventilation. It consists of deep inhalation followed by forced exhalation and cough $(24,25)$.

Cough education is important for patient with TB and consist of: body positioning during coughing, control of breathing in coughing (slowly nose inspiration, short apnoea and strong air expiration in 2-3 sessions). The goal is to achieve mobilization and secretions removal from the bronchial tree.

\section{Exercise training}

The post TB sequelae may have functional consequences such as obstructive or restrictive function and decreased effort tolerance; patients with frequent relapses may have cachexia, asthenia and muscle fatigue. In these cases, there is a rationale for exercise training as part of the rehabilitation programmes (26).

A Japanese study assessed effort tolerance in 10 patients with post TB sequelae by using cardiopulmonary exercise test (CPET) before and after 2 weeks of exercise training. The exercise programme consisted of daily walking in the hospital corridor, and the results were positive: increase of maximum oxygen uptake (from $13.6 \pm 2.8$ to $14.8 \pm 2.8 \mathrm{ml} / \mathrm{kg} / \mathrm{min}$, $p<0.01$ ) and 6 MWT distance (from $399 \pm 62$ to $467 \pm 65 \mathrm{~m}$, $p<0.01$ ) (27). Although there was a small number of patients and the duration was short, this study showed how useful is walking as an exercise. Another prospective nonrandomized open trial which took place also in Japan compared the results of a nine-week outpatient $P R$ programme in 32 post TB patients and 32 COPD patients. The positive effects were similar to the two groups, in terms of exercise tolerance
(6MWT distance), dyspnoea (MRC scale) and daily activities scores (23).

A research was conducted in Colombia and assessed the PR effects on aerobic capacity and health-related QOL in eight patients with TB sequelae. It was an 8-week PR programme, including physical aerobic training, therapeutic education and activities of daily living. The sessions took place three times per week. Exercise training was aerobic, performed on a treadmill for lower limb, with training intensity starting from $60 \%$ and reaching $90 \%$ of the maximum oxygen consumption. The results were positive: increase of peak oxygen consumption (VO2) with $1.7 \mathrm{ml} / \mathrm{kg} / \mathrm{min}$, 6MWT distance with $63.6 \mathrm{~m}$ and improvement of SGRQ score with 13 points (28).

Another study performed in Uganda on 34 patients with posttuberculous lung disorder and respiratory symptoms (mMRC dyspnoea score >2) used a 6-week PR programme, two sessions per week. The PR programme consisted of lower limb aerobic training, with intensity seat in order to reach $80 \%$ of the peak values obtained at Incremental Shuttle Walking Test (ISWT), and resistance training for upper and lower limbs (weights). Patients received also therapeutic education, regarding long-term effects of TB, self-management and nutrition. Improvements were obtained in QOL (reduction of mean CCQ score from 1.8 to 1.0 ), exercise tolerance (increase of ISWT distance from 299 to $377 \mathrm{~m}$ ), diminution of chest pain (from $45 \%$ participants to $24 \%$ ) and haemoptysis (from 17 to $7 \%$ ) (7).

An outpatient PR programme from India searched for the effects of PR in 29 patients with chronic lung impairment from previously treated tuberculosis (CLIPTB). The PR programme had a 8-week duration, sessions three times per week, including exercise training for lower limbs (ergometry and treadmill) and upper limbs (arm ergometry and weights) and therapeutic education. The intensity of the exercises increased progressively, according to symptoms. The results were positive in terms of 6MWT distance (488 $\mathrm{m}$ at baseline vs. $526 \mathrm{~m}$ post $\mathrm{PR}$ intervention) and chronic respiratory questionnaire (CRQ) score (17.21 at baseline vs. 18.96 post PR) (29).

By resuming, for the evaluation of PR programmes results in patients with TB, the parameters used were as follows:

- exercise tolerance with 6MWT $(22,23,29)$, ISWT (7) and CPET (28).

- QOL with SGRQ (St George Respiratory Questionnaire) (22, 28), CCQ (Clinical COPD Questionnaire) (7), WHOQOL-100 (quality of life of the World Health Organization) (5), CRQ (29).

For establishing the intensity of training, the data from exercise tests may be used, or in the absence, the symptom tolerance. In the studies published so far, programme design was almost 
similar to the one recommended for COPD. The length of the PR programme varied from 2 weeks (27), 4 weeks (30), 6 weeks $(7,30)$ to $8(22,28)$ and 9 weeks $(23)$.

\section{Programme Location}

The PR programme settings may differ regarding the patient's status and healthcare system possibilities. The old sanatorium providing physiotherapy for patients with TB may be transformed these days in most attractive and modern PR centres (31).

In the active phase, when the patient is contagious, the hospital PR programmes are more suitable $(5,27)$. In post TB sequelae, the majority of rehabilitation programmes were conducted in outpatient settings $(7,23,29)$. One pilot study performed in South Africa showed the utility of a 6-week home-based PR programme, in patients with TB (30), while other programme used home-based care programme for multi drug resistant (MDR)-TB patients with TB (32).

\section{Pulmonary rehabilitation in MDR tuberculosis}

MDR-TB patients with TB face multiple challenges, related to destructive effects of the disease on lung function, cachexia and functional incapacity, treatment duration and adverse effects. These patients are hospitalized for a long period of time, which predisposes to the muscle deconditioning but also to depression (33), social isolation and impaired QOL. The PR programme in their case should be started as soon as their condition becomes stable and include exercise training (aerobic and endurance), nutrition support and psychological counselling. A very important part is represented by the education that aims to improve the long-term adherence to treatment and the participation in daily life activities and social reintegration. The palliative care should also be included in very severe patients with MDR-TB $(32,34)$.

An Indian research emphasized the benefits of a homebased care programme for patients with MDR-TB. The study had a control group (50 MDR-TB patients with TB who received standard drug therapy) and a study group (50 MDR-TB patients receiving standard treatment plus home-based care - rehabilitation, nutritional support and counselling). The home care group patients faced less rejection from family members (6 vs. $26 \%$ ) or community rejection (10 vs. $28 \%$ ) and a smaller number of them loss their job versus standard care group (5 vs. 13 patients). Regarding the treatment, in the home care group, $40.6 \%$ of patients completed the treatment and $12.5 \%$ were defaulter versus $23.6 \%$ treatment completion and $23.7 \%$ defaulter in the control group (35).

Pulmonary rehabilitation in tuberculosis pleural effusion In the active phase of TB pleurisy, the physiotherapy has the role of fibrosis prevention, but also postural and analgesic.
The major position will be in decubitus, but alternating with lateral position and procubitus. The scope is to favour pleural effusion resorption; for the pain massage can be used. In order to mobilize the diaphragm expansion and recovering the lung reserve volumes, abdominal - diaphragmatic breathing, thoracic mobilization against a resistance (manually, with sandbags) can be used. After 1 month, the rib expansion exercise can start asymmetrical suspension with the espalier, swimming (crawl) (36).

Sometimes, there is poor healing with pleural fibrosis and consecutively restrictive syndrome (34). In these cases, the procedures used by physiotherapist used are breathing education, exercise training, muscle tonifying and hydrotherapy (37).

\section{Conclusions}

Although TB is one of the oldest known respiratory diseases, there are few studies in scientific literature about the effects of rehabilitation programmes in TB. However, these studies are in favour of using PR in TB patients' therapy, with positive effects on symptoms, exercise tolerance and QOL. The indications can be symptomatic patients with lung destruction, reduced pulmonary function, muscle weakness, decrease exercise tolerance and impaired QOL. Still, further studies with larger number of patients and control groups are needed.

The main role of PR seems to be in management of post TB sequelae, but there is positive feedback about the benefits of using rehabilitation from the active phase of disease. Recovering the physical and functional status of patients with TB, together with psychological support can shorten the convalescent period and help the return to work.

The location and the development of these programmes depends on the health care system possibilities, especially since the high incidence of TB is in countries with loweconomic level.

\section{Conflict of interest}

The authors have no conflict of interest.

\section{References}

1. Marica $C$, Didilescu $C$, Tănăsescu M, Murgoci G, Arghir O. Compendiu de tuberculoză. București: Editura Curtea Veche; 2011, ISBN 978-973-1983-58-5, p.5.

2. WHO. 2018. Available from: https://www.who.int/news-room/ fact-sheets/detail/tuberculosis. 
3. Maguire GP, Anstey NM, Ardian M, Waramori G, Tjitra E, Kenangalem E, et al. Pulmonary tuberculosis, impaired lung function, disability and quality of life in a high-burden setting. International Journal of Tuberculosis and Lung Disease. 2009;13(12): 1500-1506.

4. Guessogo WR, Mandengue SH, Assomo Ndemba PB, Medjo UO, Minye EE, Ahmaidi S, et al. Physical and functional followup of tuberculosis patients in initial intensive phase of treatment in Cameroon using the 6-min walk test. Journal of Exercise Rehabilitation. 2016;12(4): 333-339.

5. Nogas A, Grygus I, Nagorna O. Results of the physical rehabilitation of patients with pulmonary tuberculosis. Journal of Physical Education and Sport, 2019;19(1), Art 98: 684-690.

6. Daniels KJ, Irusen E, Pharaoh H, Hanekom S. Post-tuberculosis health-related quality of life, lung function and exercise capacity in a cured pulmonary tuberculosis population in the Breede Valley District, South Africa. South African Journal of Physiotherapy. 2019;75(1):1319.

7. Jones R, Kirenga BJ, Katagira W, Singh SJ, Pooler J, Okwera A, et al. A pre-post intervention study of pulmonary rehabilitation for adults with post-tuberculosis lung disease in Uganda. International Journal of Chronic Obstructive Pulmonary Disease. 2017;12: 3533-3539.

8. Tudorache VM, Lovin S, Friesen M. Tratat de reabilitare pulmonară. Ed Mirton Timisoara; 2009.

9. Spruit MA, Singh SJ, Garvey C, ZuWallack R, Nici L, Rochester C, et al. An official American Thoracic Society/European Respiratory Society statement: key concepts and advances in pulmonary rehabilitation. American Journal of Respiratory and Critical Care Medicine. 2013;188(8): e13-e64.

10. Croitoru A, Ioniţă D, Stroescu C, Pele I, Gologanu D, Dumitrescu A, et al. Benefits of a 7-week outpatient pulmonary rehabilitation program in COPD patients. Pneumologia. 2013;62(2): 94-101.

11. Chapman CE, Hollander AG. Tuberculosis and rehabilitationdynamic physical restoration of patients with active disease. California Medicine. 1964;100(2): 88-91.

12. Onwubalili JK. Malnutrition among tuberculosis patients in Harrow, England. European Journal of Clinical Nutrition. 1988;42: 363-366.

13. Baarends EM, Schols AM, Van Marken Lichtenbelt WD, Wouters EF. Analysis of body water compartments in relation to tissue depletion in clinically stable patients with chronic obstructive pulmonary disease. The American Journal of Clinical Nutrition. 1997;65: 88-94.

14. Schwenk A, Hodgson L, Wright A, Ward LC, Rayner CF, Grubnic S, et al. Nutritional partitioning during treatment of tuberculosis: gain in body fat but not in protein mass. The American Journal of Clinical Nutrition. 2004;79: 1006-1012.

15. Khan A, Sterling TR, Reves R, Vernon A, Horsburgh CR. Lack of weight gain and relapse risk in a large tuberculosis treatment trial. American Journal of Respiratory Critical Care Medicine. 2006;174(3): 344-348.
16. Paton NI, Chua YK, Earnest A, Chee CB. Randomized controlled trial of nutritional supplementation in patients with newly diagnosed tuberculosis and wasting. The American Journal of Clinical Nutrition. 2004;80(2):460-465.

17. Gupta KB, Gupta R, Atreja A, Verma M, Vishvkarma S. Tuberculosis and nutrition. Lung India. 2009;26(1): 9-16.

18. Awaisu A, Nik Mohamed MH, Mohamad Noordin N, Abd Aziz N, Syed Sulaiman SA, Razak Muttalif A, et al. The SCIDOTS Project: evidence of benefits of an integrated tobacco cessation intervention in tuberculosis care on treatment outcomes. Substance Abuse Treatment, Prevention, and Policy. 2011;6: 26.

19. Koyanagi $A$, Vancampfort $D$, Carvalho AF. Depression comorbid with tuberculosis and its impact on health status: cross-sectional analysis of community-based data from 48 low- and middleincome countries. BMC Medicine. 2017;15: 209.

20. Ayari A, Smadhi H, Mejri M, Kamoun H, Greb D, Akrout I, et al. Management of pulmonary tuberculosis sequelae. European Respiratory Journal. 2015;46(suppl 59): PA2762.

21. Tada A, Matsumoto H, Soda R, Endo S, Kawai H, Kimura G, et al. Effects of pulmonary rehabilitation in patients with pulmonary tuberculosis sequelae. Nihon Kokyuki Gakkai Zasshi. 2002;40(4): 275-281.

22. Betancourt-Peña J, Muñoz-Erazo BE, Hurtado-Gutiérrez H. Effect of pulmonary rehabilitation in quality of life and functional capacity in patients with tuberculosis sequelae. Nova. 2015;13(24): 47-54.

23. Ando M, Mori A, Esaki H, Shiraki T, Uemura H, Okazawa M, et al. The effect of pulmonary rehabilitation in patients with post-tuberculosis lung disorder. Chest. 2003;123(6): 1988-1995.

24. Danteş E, Croitoru A, Jipa D, Baciu A, Todea D. Non-pharmacological approach of bronchiectasis - The results of respiratory rehabilitation in two clinical cases. Pneumologia. 2017;66(2): 100-105.

25. Guy's and St Thomas' NHS Foundation Trust. Active Cycle of Breathing Techniques (ACBT). 2018;3607: 2.

26. Muñoz-Torrico $M$, Rendon $A$, Centis $R$. Is there a rationale for pulmonary rehabilitation following successful chemotherapy for tuberculosis? Jornal Brasileiro de Pneumologia. 2016;42(5): 374-385.

27. Yoshida N, Yoshiyama T, Asai E, Komatsu Y, Sugiyama $Y$, Mineta $Y$. Exercise training for the improvement of exercise performance of patients with pulmonary tuberculosis sequelae. Internal Medicine. 2006;45(6): 399-403.

28. Rivera JA, Wilches-Luna EC, Mosquera R, Hernandez NL, Hernandez Orobio OM. Pulmonary rehabilitation on aerobic capacity and health-related quality of life in patients with sequelae of pulmonary TB. Physiotherapy. 2015;101: e1288.

29. Singh SK, Naaraayan A, Acharya P. Pulmonary rehabilitation in patients with chronic lung impairment from pulmonary tuberculosis. Cureus. 2018;10(11): e3664.

30. de Grass D, Manie S, Amosun SL. Effectiveness of a homebased pulmonary rehabilitation programme in pulmonary 
function and health related quality of life for patients with pulmonary tuberculosis: a pilot study. African Health Sciences. 2014;14(4): 866-872.

31. Grandvoinnet P. Valoriser le patrimoine climatique: la reconversion des sanatoriums de cure antituberculeuse. In Situ [En ligne], 2017;31: mis en ligne le 23 février 2017.

32. Lange C, Aarnoutse RE, Alffenaar JWC. Management of patients with multidrug-resistant tuberculosis. International Journal of Tuberculosis and Lung Disease. 2019;23(6): 645-662.

33. Mahler B, Tanasescu M, Popescu-Hagen M, Dumitrescu A, Marica $C$. The depressive syndrome as a response to the TB treatment in MDR TB patient. ERS Annual Congress. European Respiratory Journal. 2008;32(supplement 52).

34. Tiberi S, Torrico MM, Rahman A, Krutikov M, Visca D, Silva $\mathrm{DR}$, et al. Managing severe tuberculosis and its sequelae: from intensive care to surgery and rehabilitation. Jornal Brasileiro de Pneumologia. 2019;45(2): e20180324.

35. Taneja N, Chellaiyan VG, Daral S, Adhikary M, Das TK. Home based care as an approach to improve the efficiency of treatment for MDR tuberculosis: a Quasi-Experimental Pilot Study. Journal of Clinical and Diagnostic Research. 2017;11(8): LC05-LC08.

36. Vandevenne A. Reeducation respiratoire. Bases cliniques, physiopathologie et resultats Ed. Chapter 6. Pathologie pleurale, Paris: Masson; 1999. p.207-217.

37. Mertan A. Contribution of physical therapy in the complex treatment of pachypleuritis functional reeducation. Romanian Journal of Physical Therapy. 2012;18(29): 27-37.

38. British Thoracic Society guideline for non-CF bronchiectasis. Thorax. 2010;65(suppl I). 